\title{
Efficacy of Cooperative and Self-Directed Learning Strategies in Enhancing Mathematics Achievement of Underachieving Gifted Students in Nigeria
}

\author{
${ }^{1}$ Dada Oluseyi Akintunde, ${ }^{2}$ Dada Eunice Olukemi \\ 1. Department of Vocational and Special Education, Faculty of Education, University of Calabar, Calabar, \\ Nigeria.seyidada2008@yahoo.com +2348033574471 \\ ${ }^{2}$ Periscope College Ibadan, Oyo State, Nigeria.
}

\begin{abstract}
The study investigated the efficacy of cooperative and self-directed learning strategies as intervention strategies to reverse Mathematics underachievement for mathematics underachieving gifted students in Secondary schools in Ibadan, Nigeria. Eight-Nine (89) underachieving gifted science students were identified using multi-dimensional screening and identification instrument. The instruments used include, Slosson intelligence test, school academic record, mathematics aptitude test and mathematics achievement test with acceptable reliability coefficients. The study is a quasi-experimental study of pre and post test design. Three hypotheses were generated and tested against the data collected at 0.05 level of significance. The data collected was analysed using ANCOVA and MCA. The findings of the study revealed that the treatment interventions namely cooperative and self-directed learning strategies have significant effect at $F(3,85)=$ 123.258, $p<0.05$ in enhancing mathematics achievement for the underachieving gifted science students. It was also revealed that cooperative learning is more efficacious than self-directed learning, with post means scores of 68.19 and 62.00 respectively. Recommendation was thereafter made on the use of both cooperative learning and self-directed learning strategies as intervention strategies in enhancing mathematics achievement for gifted students and particularly those who are underachieving in mathematics.
\end{abstract}

Keywords: Cooperative Learning, Self-directed Learning, Gifted Underachiever, Mathematics Achievement.

\section{Introduction}

Appropriate learning experience is critical to academic achievement; schools therefore should provide learning experiences that will optimize academic achievement for their students regardless of their ability or disability. Consequently, gifted students require specialized and effective instructional strategies to learn effectively and achieve optimally in school and later in life. If instructions are not appropriately and effectively delivered, gifted students will respond poorly and loose interest in school learning, and therefore underachieve (Reis \& Mc Coach, 2000). The issue of underachievement among gifted students seems more like a mystery than a reality, but findings from researches and literatures have shown that underachievement is possible among gifted students if learning is not effective.

It is the expectation of every society and every school that their gifted students make significant and outstanding positive contributions to their society. This perhaps is the reason why most countries of the world deliberately identify and nurture their gifted students with the aim of making them positive contributors and agents of development. Nigeria is not an exception among these nations. The Nigerian Government's major objective in respect of the education for all students is to provide opportunities for them to learn and become patriotic citizens and particularly for gifted students is to develop their talents, and natural endowments/traits in the interest of the nation's economic and technological development (FGN, 2004).

Educational and political efforts aimed at promoting education for gifted students in most nations however, contend with school instructional strategies and students' responses to school programmes. Thus, for remarkable economic and technological development in Nigeria, appropriate education for gifted youths must be ensured through effective learning experience and proper implementation of a comprehensive educational policy. The major aspects of ensuring appropriate implementation of the educational policy for learners with special needs education are in the use of effective instructional strategies through challenging curriculum specifically designed for these unique set of learners.

Despite the obvious importance of educating all students to their fullest potential, gifted students have been viewed to remain underserved and unchallenged in many regular school settings (Caroline, 2007). The students spend much, if not all, of their time in the regular classroom. The classroom teacher should therefore possess appropriate strategy to facilitate optimum learning for them; else the result is obviously underachievement. The position of professionals in gifted and talented education is that, gifted students require 
effective, appropriate and challenging instructional strategies to facilitate optimum learning (Cochram-Smith \& Zeichner, 2005; Lerine, 2006; Walsh-Glaser \& Wilcox, 2006 and Smith, 2007).

Gallagher (1991) and Rimm (1997) have suggested that the causes of underachievement should be viewed from two perspectives: environmental and personality factors. The environmental factor seems to stem from two problem areas: the school and the student's peer group. An anti-intellectual school or anti-ability school's atmosphere can contribute to underachievement behaviour. Reis and Mc Coach (2000) reported negative peer influence as a major important force blocking gifted students' high achievement. Berndt (1999) also reported gifted students in America to be having decreasing grades as they move from fall to spring, because they want to be at par with their friends. This is evident that anti-academic peer group adversely influenced achievement; and as a result, gifted students want to hide their gift. Major components of the personality factor that relates to achievement are self-concept and motivation (Mc Coach, 2000). Students, who learn to see themselves as failure, eventually begin to place self-imposed limits on what they are capable of doing. Contemporary researchers in gifted underachievers such as Reis (1995) and Whitmore (1987) have confirmed that underachieving gifted students are different from achieving gifted students in expression of low self-esteem and poor leaning motivation.

The manifestation of underachievement may also reflect a difference between what the students can learn and what they have learnt. Reis (1998) suggested that gifted students who are not challenged in school will actually not demonstrate integrity and courage when they choose to do, and may require work that is below their intellectual capacity labelling this phenomenon "dropping out with dignity". She concluded that some students may underachieve as a direct result of an inappropriate and un-motivating learning strategy. Reis, Herbert, Diaz, Maxfield and Ratley (2005) provided further evidence that underachieving students complain of boredom from a poor learning strategy that is not challenging. This may contribute greatly to underachievement.

All students need learning motivation to grow and expand in knowledge, skill, thinking and achievement. For most gifted students, the general education programmes and process alone cannot provide the need they require to remain motivated or learn at a comfortable space and pace for optimum achievement measurable to their potential abilities. Thus, gifted students complained being bored at school, another important possible explanation for underachievement and misbehaviour (Kanevsky \&Keighley, 2003). Challenging instructional strategy will thus keep gifted students engaged for optimum learning and achievement in a class of students with a wide range of abilities or levels of intelligence.

Whitmore (2006) has identified classroom modification and appropriate instructional strategies as veritable instrument that can help in reversing underachievement for students. Ufford (2008) also suggested supportive strategy, intrinsic strategy and remedial strategies as intervention strategies that can help correct underachievement in students. It should be noted however, that, any acceptable and effective strategy should achieve the aim of maximizing potential for greater achievement for underachieving gifted students particularly in Mathematics.

There seem to be no subject so central to both economic and technological development like Mathematics. This explains why Mathematics has been taken as a subject of reference in this study. Mathematics is the basis of economical and technological advancement aimed by the Federal Government of Nigeria. This perhaps explains why emphasis has been placed on teaching Mathematics in group and individualized settings and through a problem solving approach (Esan, 1999 and Garduna, 1997).

Mathematics is a living subject which seeks to understand patterns that permeate both the world around us and the mind within us. Mathematics is globally considered the basis of all science and technology. It is one of the core and compulsory subjects at primary, junior and senior secondary school curriculum. The position and the recognition of Mathematics as a subject in the school curriculum depict the significance of the crucial role it plays in the modern age. It is a fact that most career depends on Mathematics skill. A credit pass in Mathematics at SSCE is required in most courses to gain entrance into University, Polytechnic and Colleges of Education as stated in the JAMB brochure. Despite the enormous importance of Mathematics as a school subject, a requirement for daily business transaction, and skill for self accountability, a veritable tool for future career and fundamental machinery for national progress, it has been realised that Mathematics is a subject many students fear, fail and dislike (Esan, 1999)

The persistence poor performance in Mathematics in SSCE revealed by WAEC and NECO among candidates in Nigeria is a major source of worry to any concern educator. This problem can be persistent even with gifted students (especially among those not identified) if not checked. This may seriously jeopardize the aims and objectives of the government on the education for students with gifted, special gift and talent aimed to be provided for in the interest of the nation's economic and technological development. Lazurus (2010) reporting Ojeme (2008) stated that out of a total of 378,018 candidates who sat for the Nov/Dec 2007 WASSCE, only 21,148 candidates passed with credit in Mathematics and science. This statistics implies that only around $5.6 \%$ of the candidates passed Mathematics and science. She also reported the media briefing of February 15 , 2007 on the performance of students in SSCE by WAEC, that out of a total number of 423,578 candidates who 
sat for the Nov/Dec 2006 WASSCE, 48,966 candidates representing 11.5\% obtained credit in Mathematics and english language and four other subjects, and only 19,591 candidates representing $4.6 \%$ of this candidates obtained credit in Mathematics.

The result analysis of 2009 May/June WASSCE shows that 356,981 (25.9\%) out of a total of 1,373,009 candidates passed English language or Mathematics at credit level. The data shows that only 176,729 (8.5\%) are science students who passed Mathematics and three other science subjects at credit level. The report of the year also show that 109,201 (8.0\%) are involved in various form of examination malpractices (Vanquard, 2009). The performance of 2010 May/June WASSCE was not better as only 337,071 (24.9\%) passed Mathematics and English language with three other subjects at credit level. The percentage however increased in 2011 to $30.9 \%$ in WASSCE but the percentage of science students reduced drastically; only $6.9 \%$ of the science students have credit pass in Mathematics and three science subjects. (Source: www.leadership.ng/nga)

A report provided on the performance of gifted students in Federal Government Academy (FGA), Suleja, on subject achievement analysis in NECO SSCE June/July 2007, indicated that $95.5 \%$ was overall percentage credit pass in Mathematics (Gifted Touch, 2007/2008). One would then wonder why lower pass is recorded among gifted students in Mathematics, the percentage notwithstanding. The poor performance in Mathematics has often been attributed to inability of the students to maximize their potentials. In her comment in a yearly publication from the school, the principal of FGA pointed out that, in Nigeria, we are far behind in the teaching of science (of which Mathematics is major) in secondary schools as compared to other nations of the world including the third world countries (Gifted Touch, 2008). This statement should spur teachers into finding ways of improving the teaching-learning process of science subjects and particularly Mathematics which is highly germane to all other science subjects.

The trend was not different in NECO report on SSCE results. The NECO registrar Professor Promise Okpala in a press briefing has attributed the failure of the students to poor teaching and learning process. He insisted that the process has reduced the confidence of the candidates to face external examinations. This trend calls for an urgent intervention in the teaching and learning process particularly for Mathematics.

Optimum achievement in Mathematics has been viewed to be inhibited among students including gifted students. The following have been reported to have accounted for poor achievement in Mathematics: some Mathematics teachers do not understand Mathematics so well that has of course made teaching it mainly a matter of following some textbook and relying on it; the teachers' and parents' view of Mathematics is that, Mathematics is a segmentation calculation rules that can only be memorized; the inability of teachers to use appropriate techniques or strategy because of the believe that Mathematics is abstract and not lively and that gifted students can cope; the authoritative approach of teachers in Mathematics class; the low self-esteem of the gifted learners particularly the girls towards Mathematics; the discouragement in class and poor attitude of peers towards Mathematics achievement of gifted students and teachers often believe that gifted students have no problem in understanding Mathematics, thus, they do not seem to have reasons for using any specialized instructional strategy (Smith, 2001 and Johnson, 2000). Thus, this is a serious gap that calls for urgent attention if the objective of developing the nation technologically and economically will be realistic.

Although Mathematics is based on rules that must be learned, it is important for motivation that students develop beyond the memorizing the Mathematics rules. The possibility of achieving appropriate development of Mathematics knowledge and application demands transformation which is possible though: seeking solution to problem, not just memorizing procedures; exploring pattern, not just knowing formula and formulating conjectures and applying them to real life situation, not just doing exercises

This transformation suggests differentiate instruction on both curricular content and instructional pedagogies particular for gifted students who cannot achieve their Mathematics potential with ordinary or common instructional style.

The tenet of differentiated instruction however, supports both the equity and the teaching principle of standards for school Mathematics for gifted students (NCTM, 2000). These principles should direct the selection and adaptation of curriculum and its delivery to meet the interests, abilities, and learning need of all students and particularly the gifted students; recognizing their diversity and thereby encourage them to attain their full potential in Mathematics. In most schools, Mathematics is taught as "here are the rules, memorize them, and we will drill them for the rest of the lesson". This approach does not promote conceptual understanding nor tie the concept together. The memorized, non-understood form of learning Mathematics can quickly faint from memory. Thus, teachers of the gifted learners must understand very well concepts of Mathematics to be taught and use the most motivating strategy to achieve optimum understanding in learners (Johnson, 2000). It is therefore important to note that Without appropriate teaching strategy, student will learns but very little in Mathematics and this may not give them optimum understanding and application of Mathematics concepts. Interestingly the gaps identified above can be bridged with appropriate learning strategies that will help improve self-concept, self-confidence, interest and consequently optimise academic achievement in Mathematics and 
Mathematics related disciplines. Two of such learning strategies are cooperative learning and self-directed learning strategies.

Cooperative learning strategy is one of the success stories of global educational reforms. It has solid teacher support and a favourable research base (Adams \& Hamm, 2006). In Cooperative learning, students are partnered with peers in working together in group work with definite objectives. Cooperative learning is a strategy that can combine both arrangement and technique. Cooperative learning has some attributes that has of course given it a global acceptance among scholars. These attributes include positive interdependence, face-toface interaction, individual accountability, personal responsibility for reaching group goals, interpersonal skills and regular group processing and reflection (Adams \& Hamm, 2006). Research has indicated that cooperative learning strategy promotes students learning, increase students' retention, enhanced students' academic achievement, develops students' social skills, and promotes self-esteem (Davis \& Roger, 2001).

Some gifted students have also been referred to as independent learners who are self-motivated (DECS, 1996) and self-sufficient (Clark, 1992). Treffinger (1994) described self-directed learning as an outcome to be strived for by the gifted students. Self-directed learning for students was described by Treffinger in terms of students managing instructional decisions and defining projects to accomplish in self-initiated goals and objectives. Sternberg (1997) also emphasized self-management when he referred to gifted students as good mental self-managers because they are able to combine analytic, synthetic and practical abilities.

Professionals have consistently argued for differentiated education for gifted students. They posited that a goal of education for gifted students is that it should be self-directed learning. Researchers have indicated also that gifted students are independent in thought and judgment, as well as self-starting, and perseverant. Thus, Treffinger (1995) emphasized the importance of creating an environment in which learners can manage and direct their efforts towards the attainment of specific goals in learning areas. Treffinger described self-directed learning in terms of the process of moving from teacher prescribed class activities, to providing choices and options to students, and then to the learner controlling the choices while the teacher provides the resources and materials. Emphasis was placed on both cognitive and affective processes, that, they are to be involved and developed. Self-directed learning accommodates the two processes, but the skills are acquired through planned instructional experiences. Maker and Nielson (1995) argued that the skills of self-management and self-direction will enable students to do an in-depth investigation on problems such as provided in Mathematics.

Many experts have addressed the importance of self-directed learning and of giving students time to pursue their own interests during the school day. Delisle (1999), for example, spoke about giving students the opportunity to plan his or her individual learning. Van Tassel-Baska (1986) and Clark (1997) indicated the importance of student's choice in curriculum and the associated self-discovery for maintaining motivation in academics and meeting the personal and interpersonal needs of the child. Smutny, Walker, and Meckstroth (1997) describe this as a balance between total group instruction and individualized learning time. Torrance (1962) demonstrated that students who are given the opportunity to learn what they want to learn in any subject area such as Mathematics, instead of what they have to learn, "fall in love" with their topics, go beyond the level of interests or hobbies and develop passions. As a result the students spend more time pursuing knowledge in these areas.

Indeed, gifted students are more independent than other students.

\section{Statement of the problem}

Understanding the causes of underachievement is only the first step to solving the spectrum of problems among underachieving gifted learners. The identification of Mathematics underachieving gifted science students remains a serious challenge. Though, some informal measures of identification are in use, the most serious problem which is the concern of this study is what are the appropriate interventions necessary to correct Mathematics underachievement particularly among gifted science student? It is understandable that proposed interventions have taken several different directions in many parts of the world, but these interventions are undermined by cultural variations and student interest as reviewed in literatures.

\section{Hypotheses}

The following Null hypotheses (Ho) were tested in the study at 0.05 level of significance.

1. There is no significant main effect of treatment on Mathematics achievement of underachieving gifted science students.

2. There is no significant main effect of level of intelligence on Mathematics achievement of underachieving gifted science students.

3. There is no significant interaction effect of treatment and level of intelligence on Mathematics achievement of underachieving gifted science students. 


\section{Research Methodology}

This study adopted a pre-test, post test, control group, experimental research design. The design

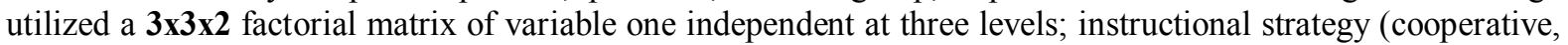
self-directed and conventional strategies), two moderator variables; level of intelligence at three levels (high, superior and very superior), the gender at two levels (male and female) and Mathematics achievement as dependent variable. The instruments used in the study are the following. The gender was not discussed because it has no significant effect.

1. Slosson Intelligence Test Third Revised Edition (SIT-R3)

2. School Academic Records

3. Mathematics Achievement Test for Senior Secondary Student (MATSSS)

4. Mathematics Aptitude Test for High School Student (MAPTHSS)

The reliability co-efficient of SIT-R3 is 0.96 , MAPTHSS is 0.87 , MATSSS is 0.89 for part 1 and 0.86 for part 2. These values indicated that the instrument is reliable.

Treatment Procedure: The participants selected through multi-stage screening and were trained on their various roles to ensure success in the research exercise. Teachers' role in cooperative learning and self-directed learning was explained to the teachers by the researcher. The participants for the study were also trained on their respective instructional strategies. This training process took two weeks. Thereafter, the treatment delivery proper and evaluation process took eight (8) weeks. Eighty (80) minutes each in two convenient days was chosen in each week for cooperative learning while any convenient days was allowed in self-directed learning. The treatment was delivered as designed in the treatment package. The summary of the treatment procedure was given in table1 below

Table 1 Procedure for the treatment

\begin{tabular}{|l|l|}
\hline Weeks & Activities \\
\hline $1-2$ & Screening for participants for the study and pre treatment testing \\
\hline $3-4$ & Training of the teachers, students and assigning students to their experimental groups \\
\hline $5-11$ & Treatment delivery using cooperative learning and self-directed learning strategies to the participants \\
\hline 12 & Post treatment assessment of the participants \\
\hline
\end{tabular}

The inferential statistics of ANCOVA was used to test the stated null hypotheses at 0.05 level of significance. The multiple classification analysis MCA was also employed in order to find out the magnitude of the mean achievement in the different groups.

\section{Presentation of Analysis, Results and Discussion}

Table 2 Analysis of Covariance of Post Test Mathematics Achievement of the Treatments and Control

\begin{tabular}{|l|l|l|l|l|l|}
\hline Source & Sum of square & Df & Mean Square & F & Sig. \\
\hline Corrected Model(Explained) & $17211.30^{\mathrm{a}}$ & 3 & 5737.10 & 89.00 & .00 \\
Covariate (Pretest) & 1778.78 & 1 & 1778.78 & 27.60 & .00 \\
Main Effects: & & & & & \\
Treatment group & 15889.92 & 2 & 7944.96 & 123.26 & .00 \\
Error (Residual) & 5478.95 & 85 & 64.46 & & \\
Total & 22690.25 & 88 & & & \\
\hline
\end{tabular}

The null hypothesis 1 stated above assumed that the treatments; cooperative and self-directed learning have no significant main effect on the Mathematics achievement of the participants. In the table above, $\mathrm{F}(3,85)$ $=123.26, \mathrm{p}<0.05$, it was observed that there is significant main effect of treatments on post test Mathematics achievement of Mathematics underachieving gifted science students. This implies that Mathematics achievement was enhanced and improved through the use of the cooperative and self-directed strategies. The null hypothesis is rejected at $\mathrm{F}(3,85)=123.26, \mathrm{p}<0.05$. The result of the analysis of the hypothesis implies that both treatment strategies; cooperative and self-directed learning have significant effect in enhancing Mathematics achievement for underachieving gifted science secondary school students. The table 3 below shows the mean scores of the different groups. 
Table 3:Multiple Classification Analysis (MCA) Showing the Direction of the Post Treatment Analysis.

\begin{tabular}{|l|l|l|l|l|l|}
\hline Variable + category & $\mathrm{N}$ & $\begin{array}{l}\text { Unadjusted } \\
\text { Variation }\end{array}$ & Eta & $\begin{array}{l}\text { Adjusted for independent } \\
+ \text { covariates deviation }\end{array}$ & Beta \\
\hline Grand Mean $=56.49$ & 32 & 11.69 & & 12.17 & \\
\hline Treatment Groups: & 29 & 5.51 & & 5.19 & \\
Seoperative learning strategy & & & \\
Control group & 28 & -19.07 & .82 & -19.28 & .76 \\
\hline $\begin{array}{l}\text { Multiple R- squared } \\
\text { Multiple R }\end{array}$ & & & & & .87 \\
\hline
\end{tabular}

In the table, the mean scores of the different groups are as follow:

Cooperative learning (Grand mean $(56.49)+11.69)=68.19$

Self-directed Learning (Grand Mean $(56.49)+5.51)=62.00$

Control Group (grand mean $(56.49)-19.07)=37.43$

The above result showed that the cooperative learning strategy had the highest mean score; this is followed by self-directed learning strategies and lastly, the control group.

Table 4: Analysis of Covariance of Post Test Mathematics Achievement by Level of Intelligence.

\begin{tabular}{|l|l|l|l|l|l|}
\hline Source & Sum of square & Df & Mean Square & F & Sig. \\
\hline Corrected Model(explained) & $1882.162^{\mathrm{a}}$ & 3 & 627.39 & 2.56 & .06 \\
Covariate (pretest) & 1258.924 & 1 & 1258.92 & 5.14 & .03 \\
Main effects: & & & & & \\
Level of Intelligence & 560.785 & 2 & 280.39 & 1.15 & .32 \\
Error (residual) & 20808.086 & 85 & 244.80 & & \\
Total & 22690.247 & 88 & & & \\
\hline
\end{tabular}

The result of the analysis reveals in the table $4 \mathrm{a}, \mathrm{P}<0.05, \mathrm{~F}=1.15$ implies that the level of intelligence of the underachieving gifted science students has no significant effect on their Mathematics achievement. In other words, the pre test mean scores of participants classified by their level of intelligence into very superior, superior and high intelligence are not significantly different. Therefore, the Null hypothesis 2 is accepted. Thus, the levels of intelligence (high, superior or very superior) are not significant to Mathematics achievement of underachieving gifted science students. Table $4 \mathrm{~b}$, provides the post test mean scores of the various levels of intelligence.

Table 4: Multiple Classification Analysis (MCA) Showing the Direction of the Post Treatment Analysis by levels of Intelligence

\begin{tabular}{|l|l|l|l|l|l|}
\hline $\begin{array}{l}\text { Variable + Category } \\
\text { Grand Mean = 56.49 }\end{array}$ & $\mathrm{N}$ & $\begin{array}{l}\text { Unadjusted } \\
\text { Variation }\end{array}$ & Eta & $\begin{array}{l}\text { Adjusted } \\
\text { independent } \\
\text { covariates } \\
\text { deviation }\end{array}$ & $\begin{array}{c}\text { Beta } \\
+\end{array}$ \\
\hline $\begin{array}{l}\text { Levels of Intelligence: } \\
\text { High Intelligence IQ =120-131 }\end{array}$ & & -.45 & & 2.16 \\
$\begin{array}{l}\text { Superior Intelligence IQ =132-146 } \\
\text { Very superior Intelligence IQ }>147\end{array}$ & 31 & -1.85 & & -.362 \\
& & 6.51 & .17 & 1.07 \\
\hline $\begin{array}{l}\text { Multiple R - Squared } \\
\text { Multiple R }\end{array}$ & & & & & .083 \\
\hline
\end{tabular}

In table $4 \mathrm{~b}$, the mean scores of the different levels of Intelligence are revealed as follows:

High Intelligence (Grand mean (56.49) -.45) = 56.04,

Superior Intelligence (Grand mean $(56.49)-1.85)=54.65$,

Very superior Intelligence (Grand mean $(56.49)+6.51)=63.00$

The above mean scores show that, the very superior intelligence group had the highest post test mean score, followed by the high intelligence group and lastly the superior intelligence group. These imply that though the level of intelligence is not significant in Mathematics achievement, the group with very superior IQ remains at the top of achievement followed by those students with high IQ. The students with superior IQ have the least mean score. The sequence of this result calls for a concern; it however has significant implication on ability grouping of students. 
Table 5: Analysis of Covariance of the Interaction of Treatment and Levels of Intelligence

\begin{tabular}{|l|l|l|l|l|l|}
\hline Source & Sum of square & DF & Mean Square & F & Sig. \\
\hline Corrected model(Explained) & 18310.60 & 9 & 2034.51 & 36.70 & .00 \\
Covariate (pretest) & 630.04 & 1 & 630.04 & 11.37 & .00 \\
Main Effects: & & & & & \\
Treatment Groups & 10464.95 & 2 & 5232.48 & 94.38 & .00 \\
Intelligence Groups & 306.03 & 2 & 153.01 & 2.76 & .07 \\
2-way Interactions; & & & & & \\
Treatment Groups x intelligence level & 751.99 & 4 & 188.00 & 3.39 & .01 \\
Error (Residual) & 4379.65 & 79 & 55.44 & & \\
Total & 22690.25 & 88 & & & \\
\hline
\end{tabular}

In the table above, it is observed that considering the main effects, treatment was significant $(\mathrm{F}=94.38$, $\mathrm{P}>0.05)$ but the level of intelligence was not significant $(\mathrm{F}=2.46, \mathrm{P}>0.05)$. However the interaction effects, has significant difference $\left(\mathrm{F}_{(9,79)}=3.391, \mathrm{P}<0.05\right)$.

The implication of this analysis is that if the post-test mean scores of the participants are considered by their levels of intelligence only, no significant difference is observed. There is however significant difference in the participants post test mean scores when their level of intelligence was interacted with the treatment; cooperative and self-directed learning strategies. Therefore Null hypothesis 3 is rejected. So there was significant effect of the interaction of treatment and level of intelligence on Mathematics achievement of underachieving gifted science students.

\section{Discussion of Findings and Educational Implication \\ Effect of the Strategies on Mathematics Achievement}

The major focus of this study was to determine the efficacy of cooperative and self-directed learning strategies on the Mathematics achievement of underachieving gifted science students. The result of the analysis of the data obtained in the experiment $\mathrm{F}_{(3,85)}=123.258, \mathrm{p}<0.05$ with respect to hypothesis one which state that there is no significant main effect of treatment on Mathematics achievement of underachieving gifted science students revealed that the null hypothesis is rejected. The findings have clearly shown that the two instructional strategies, cooperative learning and self-directed learning have significant effect on the Mathematics achievement of underachieving gifted science students. The two strategies improved the Mathematics achievement of the participant significantly when compared with the control group. The interpretation of this is that the underachieving gifted science students in cooperative learning and self-directed learning performed significantly better in the post test than those in the control group.

The multiple classification analysis (MCA) was used to reveal the means scores of the treatment and the control group. The MCA result shows that the participants under cooperative learning strategy have the highest mean score $x=68.19$ followed by those in the self-directed learning strategy $x=62.00$. Thus the cooperative learning strategy is more effective than the self-directed learning strategy.

This result lent credence to the previous empirical findings on the effectiveness of cooperative and selfdirected learning strategies on the academic achievement of students. Esan (1999) in his Ph.D work on Effect of cooperative and individualistic problem-solving strategies on students' learning outcomes in secondary school Mathematics reported in his findings that cooperative and individualistic problem solving enhanced Mathematics achievement $\left(\mathrm{F}_{21302}=28.38 ; \mathrm{p}<0.05\right)$. The study of Hushand (1940) and Kingman (1994) reported in Esan (1999), that cooperative learning environment improved Mathematics solving skills also confirms with the present findings of this study.

Meanwhile, Johnson 2002 in his findings reported that cooperative learning is considerably more effective than competition or individualistic learning in Mathematics. This findings support the findings of this study with cooperative learning group having a higher post-test mean score $(x=68.19)$ than the self-directed learning group $(\mathrm{x}=62.00)$, although the difference is not statistically significant.

The findings of Sherman and Thomas (1986) in their study on Mathematics achievement in cooperative versus individualistic goal-structures in high school classroom reveals that there is significantly higher Mathematics achievement in cooperative learning as compared to individualistic approach. This supports the present findings of this study.

The work of Slavin (1990), Sharan (1992), Robison (1990) and Feilder et al (2002) all posited that cooperative learning benefit students with exceptional ability cognitively and affectively. Their various findings proved that cooperative learning is effective in enhancing Mathematics learning and achievement. These findings corroborate the findings of this study. Massachisetts Advocacy Centre (1990) specifically advocated for the use cooperative learning for gifted learners in primary and secondary schools. This advocacy justifies and supports the findings of this study, hence, the recommendation of cooperative learning strategy for gifted students.

Fakolade (2004) on the other hand, reported that self-directed learning model was significant to academic performance of gifted students. In his experimental study on the efficacy of enrichment triad and self- 
directed learning models on the academic performance of gifted students, the result of the analysis of the post test score was $F(3,74)=49.5 p<0.05$ on the effect of the treatment. This shows that there is significant effect of the treatment on the academic performance. He then concluded that enrichment triad and self-directed learning models are effective in enhancing academic achievement of gifted students.

The success of cooperative learning in classroom is however dependent on the teachers' quality and commitment. Cohen (1994) evaluated the teachers' quality of cooperative learning and found that only $24 \%$ of the teachers who engaged in cooperative learning attained the medium level of achievement. The majority of the teachers extemporise with cooperative learning and focus on the basic lower level skills at the exclusion of enriching differentiated learning for gifted students. It is therefore important to note that regardless of the effectiveness of teaching-learning process, it is critical to have competent and committed teachers for meaningful learning to take place (Nwazuoke, 2000).

As we grasp for resolution, it would be averred that well-intentioned teachers frequently misused cooperative learning because they improvise often and so deviate from the integrity of the strategy. Another study by Antil, Jenkins, Wayne and Vadasy (1998) investigating the use of cooperative learning by teachers ( $\mathrm{n}=$ 85 ), found that only $29 \%$ of the participants could recall any researchers or developer who influenced their implementation of the use of cooperative learning strategy. One third of the teachers made a point that, they distinguish their version of cooperative learning from the formal version, which they found to be too restrictive and exacting. Only 5\% of the teachers met the Johnson and Johnson's (1991) five elements of the standard for adherence to a true cooperative learning strategy. Teachers should therefore be trained to rise to the demand of the implementation of a true cooperative learning particularly for gifted learners.

The use of cooperative learning in schools should not however, impair student's interest on their choice of self-directed learning. Even though there is a high mean score in the post treatment score of the participants in the cooperative learning as compare to self-directed learning; $x=68.19$ and $x=62.00$ respectively, students' interest in the choice of strategy needs to be considered. Student's interest is highly critical to the cooperation a teacher could receive from a student. The teacher would rather experience frustration if students are not interested in his/her learning strategy. So, while some gifted students are interested in cooperative learning, other may not, but prefer self-directed learning as a means of differentiating their learning. Teachers should therefore ensure that all students, particularly, gifted students are placed in the learning strategy of their interest to avoid total failure.

\section{Influence of level of intelligence on Mathematics achievement of Gifted Students.}

Over the years there has been a strong debate on whether heterogeneous or homogeneous grouping is appropriate for exceptional learners. Johnson et al (1990), Kagan (1992) and Mills and Cottell (1998) encourage heterogeneous group, reflecting varied learning abilities, ethnic and linguistic diversity. Spear (1992) likewise supported grouping practices for broad peer interaction to allow socialisation using appropriate learning models, and adjust to a variety of peer influences. Some professionals however object to heterogeneous grouping. They claimed that grouping gifted or gifted students with students of average or below average together is rather resulting to underachievement and destroying potentials. Others posited that students with high intelligence may underachieve because of specific learning disability, for instance in Mathematics (dyscalculia). This learning disability may not provide such students with opportunity of being grouped with high achievers. These arguments necessitate the investigation on the influence of level of intelligence on the gifted learners.

The null hypothesis $\mathbf{2}$ which states that there is no significant main effect of level of intelligence on Mathematics achievement of underachieving gifted science students; was considered on the influence of levels of intelligence (high, superior and very superior) on Mathematics achievement of underachieving gifted science students. The result of the analysis of the data with respect to hypothesis 2 in the study at $\mathrm{F}=1.15$, $p>0.05$ (Table 4.4) proved insignificant. On this ground the levels of intelligence have no main significant effect on the Mathematics achievement of underachieving gifted science students. The implication of these findings is that grouping can be either heterogeneous or homogenous. The ratio of the grouping should however be carefully considered. From the MCA result of the study on the effect of level of intelligence on the Mathematics achievement, it was found that the post test mean scores of the participants in the very superior intelligence group was the highest (63.00), followed by those with high intelligence (56.04) and the least was those with superior intelligence (54.64). The sequence of the result calls for a concern; nonetheless these findings supported the position of Mills and Cottell (1998) that, appropriate grouping should include one lowability, two medium ability and one gifted students in the ratio 1:2:1 respectively. This was contrary to the findings of Esan (1999) who reported that there was significant main effect of ability on both achievement and attitude to Mathematics. The contradiction cannot however be statistically established because a light difference exist in the conceptional frame work in his study and the present study. While Esan (1999) used only the quantitative ability to refer to ability levels, the present study employs the intelligence which refers to the general mental ability. 
Considering the hypothesis 3 which state that there is no significant interaction effect of treatment and level of intelligence on Mathematics achievement of underachieving gifted science students. It was observed from table 4.6, $\mathrm{F}=3.39 ; \mathrm{p}<0.05$ that the interaction effect of treatment and level of intelligence was significant. Another implication of these findings is that the level of intelligence only does not have significant influence on Mathematics achievement of gifted science students but it does when interacted with the learning strategies. The present study also disproved the finding of Essay (1999) that interaction effect of treatment and ability level has no significant effect on mathematics achievement. This can be argued on the basis of the choice of the cooperative technique and that individualistic problem solving does perfectly mean self-directed learning.

The findings of Ojo (1988) on the differential effectiveness of cooperative, competitive and individualistic goal structure on students' performance supported the present study that though ability level of students affect performance but not significantly $\left(\mathrm{F}_{2,10}=0.67 ; \mathrm{p}>0.05\right)$. And again that when ability level is interacted with cooperative learning a significant interaction effect is observed $\left(\mathrm{F}_{2,107}=76.29 ; \mathrm{p}<0.05\right)$.

\section{Recommendation}

The findings of this study provide the base for the following recommendations.

1. Cooperative learning and self-directed learning strategies should be adopted as pedagogies in the teachinglearning process of Mathematics to underachieving gifted science students in secondary schools.

2. Regular in-service training for the teachers in form of conferences, workshops, symposia, short term certificate and diploma courses should be given to Mathematics teachers on the nature of gifted learners and appropriate instructional interventions for them to include cooperative learning and self-directed learning and other effective interventions, that will help reduce underachievement and improve achievement.

3. School guarding counsellors should have a regular update of school academic records for the purpose of identifying students who are not maximizing their potential and thereby underachieving in academic areas. The school records can also be used for other purposive counselling in helping students towards better academic achievement.

4. Parents should support their children by providing necessary materials, textbooks, games that can enhance Mathematics intelligence, video disc on Mathematics, educative toys and Mathematics e-learning gadget. They should engage in frequent visit to school to discuss their children Mathematics problem and progress.

5. Curriculum planner should consciously build the use of cooperative learning and self-directed learning strategies into the planning and development of mathemtics curriculum.

\section{Conclusion}

The appropriate implementation of these instructional strategies in teaching-learning of Mathematics for the gifted will help in achieving the aim of sustainable economic and technological development of our nation.

\section{References}

[1]. Adams, P. and Hamm, M. (2006). Cooperative learning in Falchikov@education ed.ac uk

[2]. Berndt, T.J. 1999. Friends' influence on students' adjustment to school. Educational Psychologist, 34, 15-28.

[3]. Clark, B. (1992). The integrative education model. In J.S Renzull (Ed.), Systems and models for developing programs for the gifted and talented. Mansfield Center, CT: Creative Learning.

[4]. Clark, B. (1997). Growing up gifted: Developing the potential of children at home and at school (5th ed.). Upper Saddle River, NJ: Merrill/Prentice Hall.

[5]. Clark, B. (2002). Growing up gifted: Developing the potential of children at home and school (6th ed). Upper Saddle River, NJ: Prentice-Hall.

[6]. Clark. B (2008). Optimizing Learning. The integrative education model in the classroom. Upper Saddle River, Nj: Merrill/Prentice Hall.

[7]. Cochram, S.D and Zaichuer (2005). Teaching every student in the digital age: Universal design for learning. Alexandria, VA: Association for Supervision and curriculum development.

[8]. Cohen, E. (1994). Restructuring the classroom: Conditions for productive small groups learning. Review of Educational Research, $64,1-35$.

[9]. David, W.J \& Rim,S.B (2004). Education of the Gifted and Talented ( $5^{\text {th }}$ ed). Needham Heights, MA: Allyn \& Bacon.

[10]. Deliesle, J. (2004). Comfortably numb: A new view of underachievement Gifted Education Communicator, 35(4), 17-20.

[11]. Esan, A.O (1999). Effect of Cooperative and Individualistic Problem-Solving Strategies on Students' Learning Outcome in Secondary School Mathematics. A Ph.D thesis, University of Ibadan.

[12]. Fakolade, O.A. (2004). Efficacy of Enrichment and Self-Directed Learning Model on Enhancing Academic Achievement of Gifted Students in Selected Secondary School in Oyo State. Ph.D thesis University of Ibadan, Ibadan.

[13]. Federal Government of Nigeria (2004). National policy on education. Yaba Lagos.

[14]. Feidler, E, Langer, R \& Winebrenner, S (2002). In search of reality. Unra veling the myths about tracking, ability grouping and the gifted. Roeper Review, 24, 108-111

[15]. Gallagher, J.J. (1991). Personal patterns of underachievement. Journal for the Education of the Gifted, 14, $221-233$.

[16]. Gallagher, J.J. (2001). Unthinkable thoughts: Education of gifted students. Gifted Child Quarterly, 44, 5-12. 
[17]. Johnson DW \& Johnson RT 1991. Effects of cooperative and individualistic learning experiences on interethnic interaction. Journal of Education Psychology, vol. 73, no 3, pp 444-449

[18]. Johnson, D.T. (2000). Teaching Mathematics to gifted students in mixed-ability classroom. ERIC Digest, E594. Reston, VA: ERIC Clearinghouse on Disabilities and Gifted Education, the Council for Exceptional Children.

[19]. Kagan, S (1992). The structural approach to cooperative learning. Educational Leadership, 47(4), 12-15

[20]. Kanevsky, L., and Keighley, T. (2003). To produce or not to produce? Understanding boredom and the honour in underachievement. Reoper Review, 26, 20-28.

[21]. Larine, D.Y (2006). Multicultural gifted education. New York Teachers

[22]. Lindsey, J and Faulker, A. (1995). Report of a longitudinal study regarding the learning approaches and motivational patterns of the academically High Ability Students. Education Notes Vol..2,1.

[23]. Maker, C.J and Neilson (1995). Teaching models in education of the gifted. Rockville MD: Aspen press Ltd.

[24]. Massachuestts Advocacy Centre (1990). Locked in/locked out: Tracking and placement practice in public schools. Boston: Eusey Press.

[25]. Mc Coach, D.B 2000. The underachievement of gifted students. What do we know and where do we go? Gifted Child Quarterly, 44, $152-170$

[26]. Mills, B. J and Cottell, P.G. (1998). Cooperative learning for higher education faculty. Phonex, AZ: Oryx Press.

[27]. National Council of Teachers of Mathematics (NCTM) (2002). Principle and standards for school Mathematics calculation Nation. Reston, VA: Author.

[28]. Nwazuoke, I.A. (2000). Teachers as facilitators of gifted learners. A training workshop for teachers of the gifted and talented learners at Academy for the Gifted, Suleja, Abuja.

[29]. Pyryt, M. 1996. IQ: Easy to bash, hard to replace. Roeper review, 18(4), 255 - 258

[30]. Reis, S.M. 1995. We can't change what we don't recognize. Understanding the Special needs of Gifted and females. Gifted Child Quarterly, 31(2), 83-89

[31]. Reis, S.M. and McCoach, D.B. (2000). The underachievement of gifted students: What do we know and where do we go? Gifted Child Quarterly, 44, 152-170.

[32]. Reis, S.M (1998). Underachievement for some-dropping out with dignity for others. Communicator, $29(1), 19-24$.

[33]. Reis, S.M., Herbert,T.P., Diaz, E.P., Maxfield, L.R., and Ratley, M.E. (2005). Case studies of talented students who achieve and underachieve in an urban high school (Research Monograph 95114). Storrs, CT: University of Connectcut, National Research Center for the Gifted and Talented.

[34]. Rimm, S.B. (1997). Why bright kids get poor grades and what you can do about it. New York: Three Rivers Press

[35]. Robinson, A. (1990). Point-counterpoint: Cooperation? The argument against cooperative learning for talented students. Journal for the Education of the Gifted, 14, 9-27

[36]. Sherman LW \& Thomas M (1986) Mathematics achievement in cooperative versus individualistic goal-structured high school classrooms. Journal of Education Research, vol. 79, no 3, pp 169-172.

[37]. Slavin, R.E. (1990). Ability grouping, cooperative learning and the gifted. Journal for the education of the Gifted, 14, 3-8.

[38]. Smith, D. (2007). Giftedness and Talent Development: introduction to special education. Peabody College Vanderbilt University, Pearson, USA

[39]. Smutney, J., Walker, S., and Meckstroth, E. (1997). Teaching young gifted children in the regular classroom. Minneapolis, MN: Free Spirit.

[40]. Sternberg, R.J (1997). The sound of silence: A nation responds to its gifted. Reoper Review, 18, 168 - 172.

[41]. Torrance. (1962). Rewarding creative behaviour. Englewood Cliffs. Nj Merrill/Prentice Hall

[42]. Treffinger, D.J., (1994). Teaching for self - directed learning. A priority for the Gifted and Talented. The Gifted Child Quarterly 19, $46-59$

[43]. Treffinger, D.J. (1995). Cultivating potential-beyond 'The Gifted program'. Teaching Pre-K to 8, 18 (77, $54-57$. 